\title{
Evaluation of drug-induced hematotoxicity using novel in vitro monkey CFU-GM and BFU-E colony assays
}

\author{
Koichi Goto, Mayumi Goto, Masako Ando-Imaoka, Kiyonori Kai and Kazuhiko Mori \\ Medicinal Safety Research Laboratories, Daiichi Sankyo Co., Ltd., \\ 1-16-13 Kita-Kasai, Edogawa-ku, Tokyo 134-8630, Japan
}

(Received February 16, 2017; Accepted April 11, 2017)

\begin{abstract}
In order to evaluate drug-induced hematotoxicity in monkey cells in vitro, colony-forming unit-granulocyte, macrophage (CFU-GM), and burst-forming unit-erythroid (BFU-E) colony assays were established using mononuclear cells in the bone marrow collected from male cynomolgus monkeys. Furthermore, the effects of doxorubicin, chloramphenicol, and linezolid on CFU-GM and BFU-E colony formation were investigated using established monkey CFU-GM and BFU-E colony assays in comparison with those on human CFU-GM and BFU-E colonies acquired from human umbilical cord blood cells. Bone marrow mononuclear cells were collected from the ischial or iliac bone of male cynomolgus monkeys. The cells were subsequently processed by density gradient separation at $1.067,1.070$, or $1.077 \mathrm{~g} / \mathrm{mL}$ for CFU-GM or $1.077 \mathrm{~g} / \mathrm{mL}$ for BFU-E, and then cultured in methylcellulose medium for 9 or 13 days, respectively. A sufficient number of CFU-GM colonies were formed from mononuclear cells processed at a density of $1.070 \mathrm{~g} / \mathrm{mL}$. Moreover, the number of BFU-E colonies from the cells processed at a density of $1.077 \mathrm{~g} / \mathrm{mL}$ was sufficient for the colony assay. The number of CFU-GM or BFU-E colonies decreased after treatment with the drugs of interest in a concentration-dependent manner. Compared with human CFU-GM, monkey CFU-GM were more sensitive to chloramphenicol and resistant to doxorubicin, whereas monkey BFU-E were more sensitive to all compounds in comparison to the sensitivity of human BFU-E. In conclusion, monkey CFU-GM and BFU-E colony assays were established and considered useful tools to evaluate the differences in drug-induced hematotoxicity between species.
\end{abstract}

Key words: Monkey CFU-GM, Monkey BFU-E, Doxorubicin, Chloramphenicol, Linezolid

\section{INTRODUCTION}

Hematopoietic organs are injured by many compounds that may affect hematopoietic cell renewal system at different stages, interfering with cell proliferation and differentiation (Amess, 1993). Hematopoiesis is a complex interplay between the intrinsic genetic pathway of blood cells and their environment regulated by cytokines. With the appropriate specific growth factors, hematopoietic stem/progenitor cells can give rise in vitro to phenotypically distinct colonies of differentiated cells. Colony formation has been used as an endpoint in in vitro studies of xenobiotic myelotoxicity using human, mouse, rat, and canine hematopoietic cells (Parchment, 1998; Parent-Massin, 2001; Pessina et al., 2001; Stephenson et al., 1971; Tepperman et al., 1974). However, to the best of our knowledge, in vitro clonogenic assays using mono- nuclear cells in the bone marrow of monkeys have not yet been reported.

Hematotoxicity is one of the most common adverse effects induced by drugs. In most cases of hematotoxicity, granulocytopenia and agranulocytosis can be caused by many different drugs (Böttiger and Böttiger, 1981; Uetrecht, 1996). Doxorubicin (DOX), an anticancer drug, has been reported to induce neutropenia and thrombocytopenia in humans (Torti et al., 1985). The antibiotic agents chloramphenicol (CAP) and linezolid (LZD) are known to cause aplastic anemia (Malkin et al., 1990) and myelosuppression (Gerson et al., 2002) in humans. However, little information about the preclinical toxicity of these drugs has been reported in monkeys. Monkeys are widely used as non-human primates in the regulatory toxicity testing for drug development. Therefore, it is indispensable for drug development to analyze drug-induced hema-

Correspondence: Koichi Goto (E-mail: goto.koichi.s7@daiichisankyo.co.jp) 
totoxicity in monkeys and identify differences in hematotoxicity between monkeys and humans.

In the present study, we established monkey colonyforming unit-granulocyte, macrophage (CFU-GM) and burst-forming unit-erythroid (BFU-E) colony assays, and we evaluated the hematotoxic potential of DOX, CAP, and LZD using the colony assays. Difference in CFUGM and BFU-E colony formation between monkeys and humans was also investigated in these assays.

\section{MATERIALS AND METHODS}

\section{Test substances}

DOX, CAP, LZD, dimethyl sulfoxide (DMSO), and cremophor EL were purchased from Sigma-Aldrich Corp. (St. Louis, MO, USA).

\section{Preparation of test solutions}

Test substances were dissolved in DMSO to make $1000 \times$ stock solutions. These solutions were then diluted with phosphate-buffered saline (Life Technologies Corporation, Carlsbad, CA, USA) mixed with $0.01 \%$ cremophor EL to achieve $20 \times$ stock solutions. As a vehicle control, $0.1 \% \mathrm{DMSO} / 0.005 \%$ cremophor EL solution was prepared. Final concentrations of each test substance for the CFU-GM colony assay were as follows: 0.5, 1.5, 4.4, 13.3, and $40 \mathrm{nM}$ for DOX; and 10, 30, 100, 300, and $1000 \mu \mathrm{M}$ for CAP and LZD. Final concentrations of each test substance for the BFU-E colony assay were as follows: $0.4,1.6,6.3,25$, and $100 \mathrm{nM}$ for DOX; and 1, 3, 10,30 , and $10 \mu \mathrm{M}$ for CAP and LZD.

\section{Cells}

Bone marrow mononuclear cells which were collected from the ischial or iliac bone of a male cynomolgus monkey ( 5 to 6 years old) and processed by density gradient separation at $1.067,1.070$, or $1.077 \mathrm{~g} / \mathrm{mL}$ were purchased from Shin Nippon Biomedical Laboratories Ltd. (Kagoshima, Japan) for each assay. Human umbilical cord blood cells were purchased from AllCells, LLC (Alameda, CA, USA).

\section{Preparation of monkey bone marrow mononuclear cells and human umbilical cord blood cells}

A cell suspension was prepared by thawing frozen monkey bone marrow mononuclear cells at $37^{\circ} \mathrm{C}$. Three hundred microliters of DNase I solution $(1 \mathrm{mg} / \mathrm{mL}$, STEMCELL Technologies, Inc., Vancouver, BC, Canada) was added to the cell suspension. Twenty $\mathrm{mL}$ of Iscove's modified Dulbecco's medium (IMDM, Life
Technologies Corporation, catalog number: 31980-030) with $2 \%$ or $10 \%$ fetal bovine serum (FBS, Life Technologies Corporation, catalog number: 10082-147) was carefully added to the monkey cells or human cells, respectively, and then the suspension was centrifuged at $200 \times g$ for $15 \mathrm{~min}$ at room temperature. The resulting supernatant was aspirated carefully and the cells were re-suspended in $20 \mathrm{~mL}$ of IMDM with $2 \%$ or $10 \%$ FBS. This washing process was repeated an additional time. Next, the monkey cells and human cells were re-suspended in $2 \mathrm{~mL}$ of IMDM with $2 \%$ FBS and IMDM without FBS, respectively. A cell strainer with $100 \mu \mathrm{m}$ pores (BD Biosciences, San Jose, CA, USA) was used to obtain a uniform singlecell suspension. Cell concentration of the suspension was measured using a hemocytometer chamber. For monkey cells, IMDM with $2 \%$ FBS was added to the cell suspension to obtain a final concentration of $1 \times 10^{5}, 2.5 \times 10^{5}$, $3 \times 10^{5}, 6 \times 10^{5}$, and $1 \times 10^{6}$ cells $/ \mathrm{mL}$ for the CFU-GM colony assay; $1 \times 10^{6}, 2 \times 10^{6}, 3 \times 10^{6}$, and $4 \times 10^{6}$ cells $/ \mathrm{mL}$ for the BFU-E colony assay; $4 \times 10^{5}$ cells $/ \mathrm{mL}$ for the CFU-GM colony assay; and $3 \times 10^{6}$ cells $/ \mathrm{mL}$ for the BFU-E colony assay. For human cells, IMDM was added to make a final concentration of $4 \times 10^{5}$ cells $/ \mathrm{mL}$.

\section{Preparation of culture medium}

Media and cytokines were purchased from STEMCELL Technologies, Inc. In the present study, MethoCult H4434 and MethoCult H4230 media were selected because MethoCult H4434 was a complete methylcellulose-based medium for the growth of hematopoietic progenitor cells in colony assays of human cells, and MethoCult H4230 was suitable to prepare a similar medium to that reported previously for human CFU-GM colony assay (Pessina et al., 2001) and was used in our inhouse studies for human CFU-GM and BFU-E assays. To investigate the method of monkey CFU-GM colony assay, the following methylcellulose-based media were prepared. MethoCult H4434 medium was prepared with $1 \%$ antibiotic antimycotic solution (Sigma-Aldrich Co., Ltd.). MethoCult H4230 medium with erythropoietin (EPO) was prepared with $50 \mathrm{ng} / \mathrm{mL}$ recombinant human (rh) stem cell factor (SCF), $10 \mathrm{ng} / \mathrm{mL} \mathrm{rh}$ granulocyte-macrophage-colony stimulating factor (GM-CSF), $10 \mathrm{ng} / \mathrm{mL} \mathrm{rh}$ granulocyte-colony stimulating factor (G-CSF), $10 \mathrm{ng} / \mathrm{mL}$ rh interleukin (IL)-3, $10 \mathrm{ng} / \mathrm{mL} \mathrm{rh}$ IL-6, $1 \%$ antibiotic antimycotic solution, and $3 \mathrm{U} / \mathrm{mL}$ rh EPO because methylcellulose-based medium supplemented with rh SCF, rh IL-3, rh IL-6, rh G-CSF, rh GM$\mathrm{CSF}$, and rh EPO was used for colony-forming cell assay using monkey peripheral blood (Carlo-Stella et al., 2004). MethoCult H4230 medium was prepared with $50 \mathrm{ng} / \mathrm{mL}$ 
rh SCF, $10 \mathrm{ng} / \mathrm{mL}$ rh GM-CSF, $10 \mathrm{ng} / \mathrm{mL}$ rh G-CSF, $10 \mathrm{ng} / \mathrm{mL}$ rh IL-3, $10 \mathrm{ng} / \mathrm{mL}$ rh IL-6, and 1\% antibiotic antimycotic solution. For the human CFU-GM colony assay, MethoCult H4230 was prepared with $50 \mathrm{ng} / \mathrm{mL} \mathrm{rh} \mathrm{SCF}$, $10 \mathrm{ng} / \mathrm{mL}$ rh GM-CSF, $10 \mathrm{ng} / \mathrm{mL}$ rh G-CSF, $10 \mathrm{ng} / \mathrm{mL}$ rh IL-3, $10 \mathrm{ng} / \mathrm{mL}$ rh IL-6, and 1\% antibiotic antimycotic solution was used. For monkey and human BFU-E colony assays, MethoCult H4230 was prepared with $10 \mathrm{ng} / \mathrm{mL}$ rh IL-3, 3U/mL rh EPO, and 1\% antibiotic antimycotic solution.

\section{Preparation of assay medium}

To investigate the methods of monkey CFU-GM and BFU-E assays, $400 \mu \mathrm{L}$ of the cell suspension was added to $3.6 \mathrm{~mL}$ of the prepared methylcellulose-based medium in 14-mL BD Falcon polypropylene round-bottom tube (BD Biosciences). For CFU-GM and BFU-E colony assays, $200 \mu \mathrm{L}$ of the test solution and $200 \mu \mathrm{L}$ of the cell suspension were added to $3.6 \mathrm{~mL}$ of the prepared methylcellulose-based culture medium in 14-mL BD Falcon polypropylene round-bottom tube (BD Biosciences). Next, the tubes were mixed vigorously using a vortex mixer and allowed to stand for approximately 5 min until the bubbles dissipated.

\section{Cell culture}

One $\mathrm{mL}$ of the prepared assay medium with cells was dispensed into 35-mm tissue culture dish (AGC Techno Glass Co., Ltd., Shizuoka, Japan) by using 2.5-mL syringe (Terumo Corporation, Tokyo, Japan). Dispensing procedures were repeated for two more dishes to obtain triplicate samples for each cell concentration or each compound concentration. The medium was distributed evenly across the surface of each dish by gently tilting and rotating the dish to allow the meniscus to attach to the wall of the dish on all sides. After that, one or two dishes were placed into a 100-mm culture dish (AGC Techno Glass Co., Ltd.). An uncovered 35-mm culture dish filled with sterile water was put into each $100-\mathrm{mm}$ dish to maintain humidity. These media samples were incubated at $37^{\circ} \mathrm{C}$ in air $+5 \% \mathrm{CO}_{2}$ under saturated humidity for 9 days (for CFU-GM colony assay) or 13 days (for BFU-E colony assay).

\section{Counting the CFU-GM and BFU-E colonies}

The number of CFU-GM or BFU-E colonies in each 35-mm dish was counted after 9 days or 13 days of incubation using an inverted microscope at 40-fold magnification. A CFU-GM colony was defined as an aggregate containing 50 or more cells. A BFU-E colony was defined as 3 or more closely spaced clusters containing more than
200 well-hemoglobinized red cells.

\section{Statistical analysis}

Cell proliferation was expressed as a percentage of growth (inhibition rate) where $100 \%$ corresponds to the number of colonies in the vehicle control dishes. The concentrations that inhibited CFU-GM or BFU-E colony formation by $50 \%\left(\mathrm{IC}_{50}\right)$ and by $90 \%\left(\mathrm{IC}_{90}\right)$ were calculated from concentration-response curves in which percent inhibition was plotted against the natural logarithm of the molar concentration of the compound. SAS System Release 9.2 (SAS Institute Inc., Cary, NC, USA) was used for these statistical analyses.

\section{RESULTS}

\section{Establishment of monkey CFU-GM colony assay}

First, in order to seek an appropriate culture medium for the monkey CFU-GM colony assay, three culture media were used for bone marrow mononuclear cells processed by density gradient separation at $1.077 \mathrm{~g} / \mathrm{mL}$. As a result, 1 to 5 CFU-GM colonies/dish were detected using the MethoCult H4434 medium (Figs. 1A and 2A). However, BFU-E colonies or colonies out of recognition were also observed (Figs. 2A and 2B). Two to four CFUGM colonies/dish were observed using MethoCult H4230 with EPO (Figs. 1A and 2C); however, some BFU-E colonies were also noted (Fig. 2D). No CFU-GM colony was observed using the MethoCult H4230 medium (Fig. 1A); however, colonies out of recognition that were considered BFU-E colonies (lacking any red color) were noted (Figs. 2E and 2F).

Next, the optimal density for the gradient separation of bone marrow mononuclear cells was investigated using the MethoCult H4230 medium. For the bone marrow mononuclear cells processed by density gradient separation at $1.067 \mathrm{~g} / \mathrm{mL}, 0$ to $6 \mathrm{CFU}-\mathrm{GM}$ colonies/dish were detected at a final concentration of $2.5 \times 10^{4}$ cells $/ \mathrm{mL}$; however, no CFU-GM colonies were observed at $1 \times 10^{4}$ cells/mL (data not shown). For the bone marrow mononuclear cells processed by density gradient separation at $1.070 \mathrm{~g} / \mathrm{mL}, 49$ to $54 \mathrm{CFU}-\mathrm{GM}$ colonies/dish were observed at a final concentration of $1 \times 10^{4}$ cells/ $\mathrm{mL}, 86$ to $99 \mathrm{CFU}-\mathrm{GM}$ colonies/dish were observed at $3 \times 10^{4}$ cells $/ \mathrm{mL}$, and 138 to $166 \mathrm{CFU}-\mathrm{GM}$ colonies/dish were observed at $6 \times 10^{4}$ cells $/ \mathrm{mL}$ (Figs. $1 \mathrm{~B}$ and 3 ). However, it was not possible to accurately distinguish each individual CFU-GM colony at $6 \times 10^{4}$ cells $/ \mathrm{mL}$ because of the high density of colonies. CFU-GM colonies could also not be counted at $1 \times 10^{5}$ cells $/ \mathrm{mL}$. 


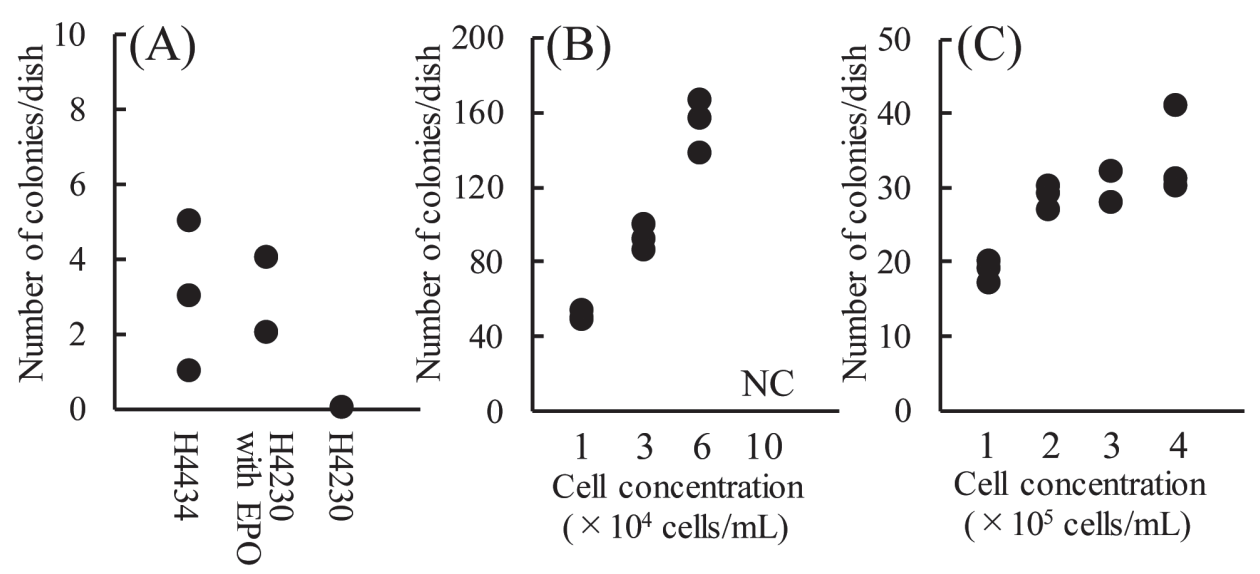

Fig. 1. Number of CFU-GM and BFU-E colonies derived from monkey bone marrow mononuclear cells. Mononuclear cells were obtained from monkey bone marrow processed by density gradient separation at $1.077 \mathrm{~g} / \mathrm{mL}$ (A and C) or $1.070 \mathrm{~g} / \mathrm{mL}$ (B). The cells were then cultured in each medium (A) or the MethoCult H4230 medium (B) for 9 days, or the culture medium for BFU-E colony assay (C) for 13 days. A CFU-GM colony was defined as an aggregate containing 50 or more cells. A BFU-E colony was defined as 3 or more closely spaced clusters containing more than 200 well-hemoglobinized red cells. H4434, MethoCult H4434 medium; H4230 with EPO, MethoCult H4230 medium with EPO; H4230, MethoCult H4230 medium. NC, Not counted in cases where there were too many colonies to count.

\section{Establishment of monkey BFU-E colony assay}

In the bone marrow mononuclear cells processed by density gradient separation at $1.077 \mathrm{~g} / \mathrm{mL}, 17$ to 20,27 to 30,28 to 32 , and 30 to $41 \mathrm{BFU}-\mathrm{E}$ colonies/dish were observed at final concentrations of $1 \times 10^{5}, 2 \times 10^{5}$, $3 \times 10^{5}$, and $4 \times 10^{5}$ cells $/ \mathrm{mL}$, respectively (Figs. $1 \mathrm{C}$ and 4). However, discolored red and misshapen colonies were noted (Fig. 4D). Moreover, many cells that did not form BFU-E colonies were also observed (Figs. 4C and 4D).

\section{CFU-GM colony assay}

DOX, CAP, and LZD inhibited monkey and human CFU-GM colony formation in a concentration-dependent manner (Fig. 5, Table 1). In the monkey CFU-GM colony assay, the $\mathrm{IC}_{50}$ was $4.90 \mathrm{nM}$ for DOX, $9.65 \mu \mathrm{M}$ for CAP, and $41.61 \mu \mathrm{M}$ for LZD; and the $\mathrm{IC}_{90}$ was $72.82 \mathrm{nM}$ for DOX, $252.23 \mu \mathrm{M}$ for CAP, and $448.35 \mu \mathrm{M}$ for LZD. In the human CFU-GM colony assay, the $\mathrm{IC}_{50}$ was $2.75 \mathrm{nM}$ for DOX, $35.41 \mu \mathrm{M}$ for CAP, and $39.01 \mu \mathrm{M}$ for LZD; and the $\mathrm{IC}_{90}$ was $27.84 \mathrm{nM}$ for DOX, $410.64 \mu \mathrm{M}$ for CAP, and $479.95 \mu \mathrm{M}$ for LZD. The inhibitory effect of three compounds on the CFU-GM colony formation was ranked in the following order: DOX $>$ CAP $>$ LZD for monkey cells and DOX $>$ CAP $=$ LZD for human cells. Furthermore, human CFU-GM was more sensitive to DOX than monkey CFU-GM, but monkey CFU-GM was more sensitive to CAP than human CFU-GM. The effect of LZD on CFU-GM colony formation was thought to be similar between monkey and human cells.

\section{BFU-E colony assay}

DOX, CAP, and LZD inhibited monkey and human BFU-E colony formation in a concentration-dependent manner (Fig. 5, Table 2). In the monkey BFU-E colony assay, the $\mathrm{IC}_{50}$ was $4.22 \mathrm{nM}$ for DOX, $4.15 \mu \mathrm{M}$ for $\mathrm{CAP}$, and $5.77 \mu \mathrm{M}$ for LZD; and the $\mathrm{IC}_{90}$ was $48.71 \mathrm{nM}$ for DOX, $16.43 \mu \mathrm{M}$ for CAP, and $33.86 \mu \mathrm{M}$ for LZD. In the human BFU-E colony assay, the $\mathrm{IC}_{50}$ was $15.15 \mathrm{nM}$ for DOX, $11.07 \mu \mathrm{M}$ for CAP, and $7.95 \mu \mathrm{M}$ for LZD; and the $\mathrm{IC}_{90}$ was $246.43 \mathrm{nM}$ for DOX, $128.75 \mu \mathrm{M}$ for CAP, and $91.66 \mu \mathrm{M}$ for LZD. Based on these data, the inhibitory effect of the three compounds on the BFU-E colony formation was ranked in the following order: DOX $>$ CAP $\geq$ LZD for monkey cells and DOX $>$ LZD $\geq$ CAP for human cells. Furthermore, monkey BFU-E was more sensitive to all three compounds than human BFU-E.

\section{DISCUSSION}

In the present study, monkey CFU-GM and BFU-E colony assays were established, and the effects of DOX, CAP, and LZD on the formation of these colonies were compared with the effect on the formation of human CFU-GM and BFU-E colonies.

In the monkey CFU-GM colony assay, the number of CFU-GM colonies was substantially increased by 
Monkey CFU-GM and BFU-E colony assays
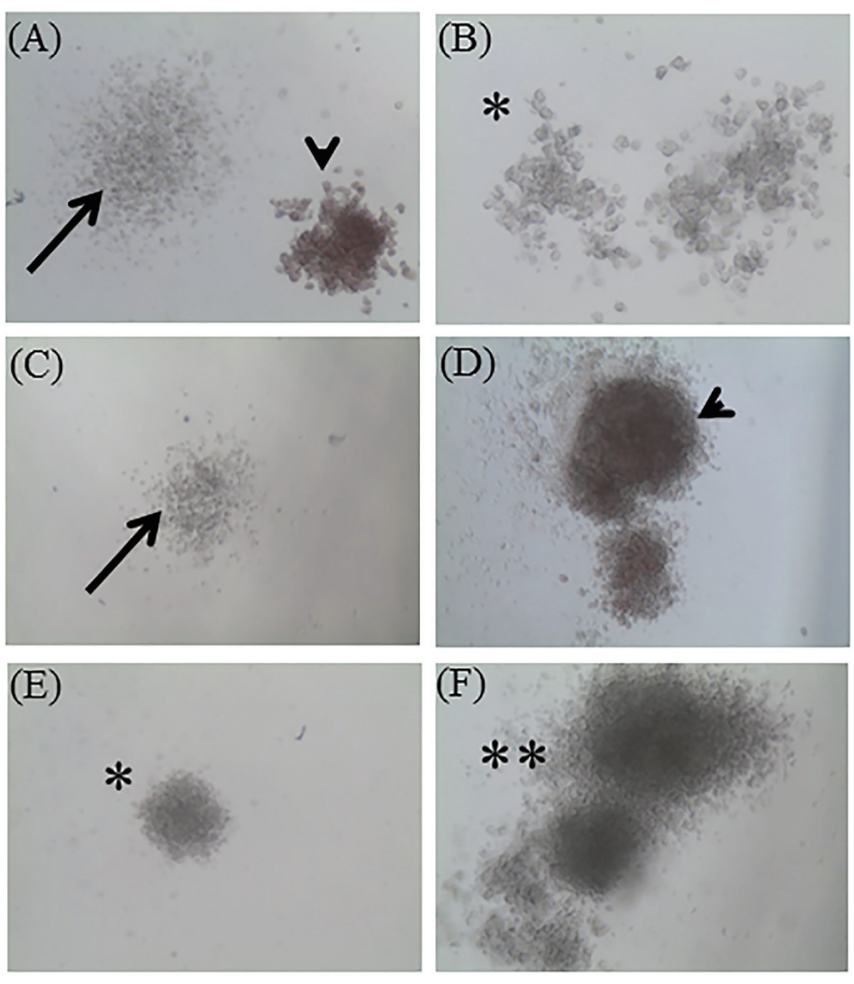

Fig. 2. Colonies derived from monkey bone marrow mononuclear cells. Mononuclear cells were obtained from monkey bone marrow processed by density gradient separation at $1.077 \mathrm{~g} / \mathrm{mL}$. Next, the cells were cultured in the MethoCult H4434 medium (A and B), MethoCult H4230 medium with EPO (C and D), or MethoCult H4230 medium (E and F) for 9 days. Final cell concentration: $1 \times 10^{5}$ cells $/ \mathrm{mL}$. Arrow, CFU-GM colony; Arrow head, BFU-E colony; *, colony out of recognition; $* *$, BFU-E colony due to absence of red color. Original magnification, $\times 40$.
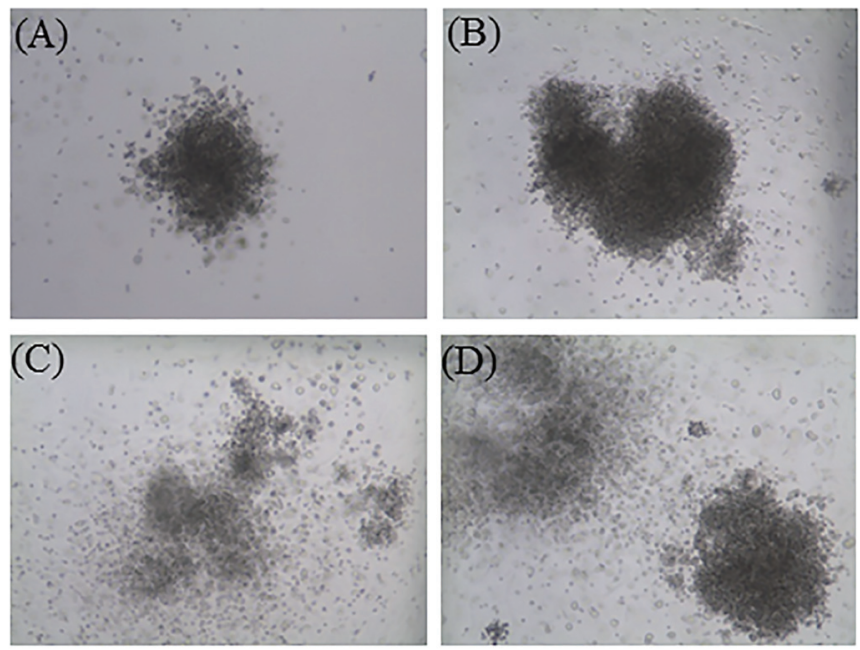

Fig. 3. CFU-GM colonies derived from monkey bone marrow mononuclear cells. Mononuclear cells were obtained from monkey bone marrow processed by density gradient separation at $1.070 \mathrm{~g} / \mathrm{mL}$. Next, the cells were cultured in the MethoCult H4230 medium for 9 days. A CFU-GM colony was defined as an aggregate containing 50 or more cells. Final cell concentration: (A) $1 \times 10^{4}$ cells $/ \mathrm{mL}$, (B) $3 \times 10^{4}$ cells $/ \mathrm{mL}$, (C) $6 \times 10^{4}$ cells $/ \mathrm{mL}$, (D) $1 \times 10^{5}$ cells $/ \mathrm{mL}$. Original magnification, $\times 40$. 

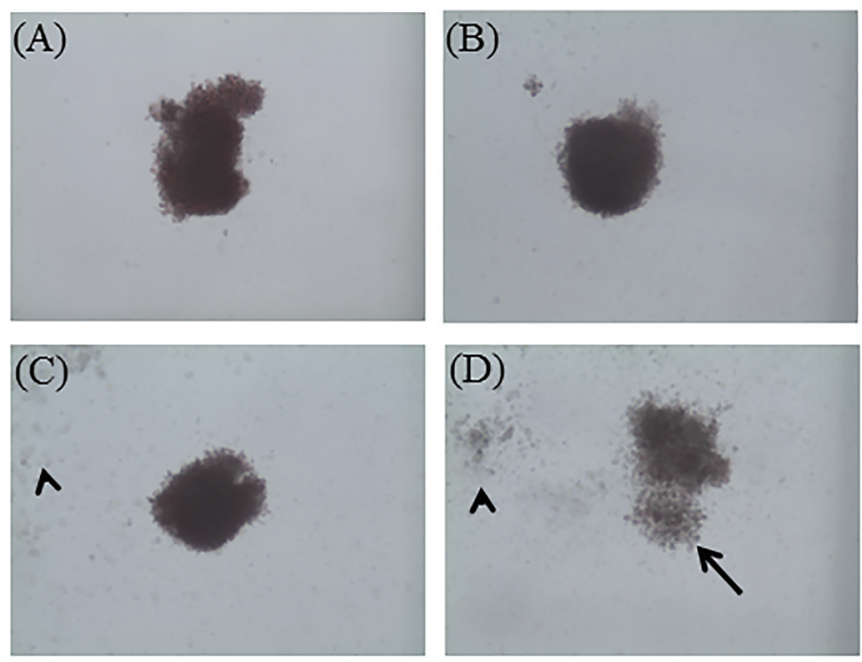

Fig. 4. BFU-E colonies derived from monkey bone marrow mononuclear cells. Mononuclear cells were obtained from monkey bone marrow processed by density gradient separation at $1.077 \mathrm{~g} / \mathrm{mL}$. Next, the cells were cultured in the culture medium specific for the BFU-E colony assay for 13 days. A BFU-E colony was defined as 3 or more closely spaced clusters containing more than 200 well-hemoglobinized red cells. Final cell concentration: (A) $1 \times 10^{5}$ cells $/ \mathrm{mL},(B) 2 \times 10^{5}$ cells $/ \mathrm{mL},(\mathrm{C})$ $3 \times 10^{5}$ cells $/ \mathrm{mL}$, (D) $4 \times 10^{5}$ cells $/ \mathrm{mL}$. Arrow: a discolored red and misshapen colony was observed. Arrow head: Many cells that did not form BFU-E colonies were noted. Original magnification, $\times 40$.

Table 1. Inhibitory concentrations of doxorubicin, chloramphenicol, and linezolid for CFU-GM formation in monkey bone marrow mononuclear cells and human umbilical cord blood cells.

\begin{tabular}{lccccc}
\hline \multirow{2}{*}{ Compound } & \multicolumn{2}{c}{ Monkey CFU-GM } & & \multicolumn{2}{c}{ Human CFU-GM } \\
\cline { 2 - 3 } \cline { 5 - 6 } & $\mathrm{IC}_{50}$ & $\mathrm{IC}_{90}$ & & $\mathrm{IC}_{50}$ & $\mathrm{IC}_{90}$ \\
\hline Doxorubicin $(\mathrm{nM})$ & $4.90(2.96,8.28)^{\mathrm{a}}$ & $72.82(32.83,299.12)$ & & $2.75(1.91,3.79)$ & $27.84(18.11,50.33)$ \\
Chloramphenicol $(\mu \mathrm{M})$ & $9.65(4.15,17.03)$ & $252.23(167.87,424.31)$ & & $35.41(26.24,45.80)$ & $410.64(308.71,580.02)$ \\
Linezolid $(\mu \mathrm{M})$ & $41.61(32.53,51.79)$ & $448.35(346.41,609,09)$ & & $39.01(29.79,49.40)$ & $479.95(362.95,672.47)$ \\
\hline
\end{tabular}

Monkey bone marrow mononuclear cells and human umbilical cord blood cells were cultured in a culture medium treated with doxorubicin, chloramphenicol, or linezolid for 9 days (CFU-GM). The concentrations that inhibited BFU-E colony formation by $50 \%$ $\left(\mathrm{IC}_{50}\right)$ and by $90 \%\left(\mathrm{IC}_{90}\right)$ were calculated from concentration-response curves in which the percent inhibition was plotted against the natural logarithm of the molar concentration of each compound. $n=3$. a: $95 \%$ confidence interval (Minimum, Maximum).

Table 2. Inhibitory concentrations of doxorubicin, chloramphenicol, and linezolid for BFU-E formation in monkey bone marrow mononuclear cells and human umbilical cord blood cells.

\begin{tabular}{|c|c|c|c|c|}
\hline \multirow{2}{*}{ Compound } & \multicolumn{2}{|c|}{ Monkey BFU-E } & \multicolumn{2}{|c|}{ Human BFU-E } \\
\hline & $\mathrm{IC}_{50}$ & $\mathrm{IC}_{90}$ & $\mathrm{IC}_{50}$ & $\mathrm{IC}_{90}$ \\
\hline Doxorubicin (nM) & $4.22(2.56,6.64)^{\mathrm{a}}$ & $48.71(27.60,108.51)$ & $15.15(7.41,40.47)$ & $246.43(77.36,2419.86)$ \\
\hline Chloramphenicol $(\mu \mathrm{M})$ & $4.15(2.73,6.00)$ & $16.43(10.83,30.47)$ & $11.07(7.03,17.79)$ & $128.75(65.02,386.85)$ \\
\hline Linezolid $(\mu \mathrm{M})$ & $5.77(3.55,9.50)$ & $33.86(18.07,108.85)$ & $7.95(5.87,10.64)$ & $91.66(59.44,163.66)$ \\
\hline
\end{tabular}

Monkey bone marrow mononuclear cells and human umbilical cord blood cells were cultured in a culture medium treated with doxorubicin, chloramphenicol, or linezolid for 13 days (BFU-E). The concentrations that inhibited BFU-E colony formation by $50 \%$ $\left(\mathrm{IC}_{50}\right)$ and by $90 \%\left(\mathrm{IC}_{90}\right)$ were calculated from concentration-response curves in which the percent inhibition was plotted against the natural logarithm of the molar concentration of each compound. $n=3$. a: $95 \%$ confidence interval (Minimum, Maximum). 

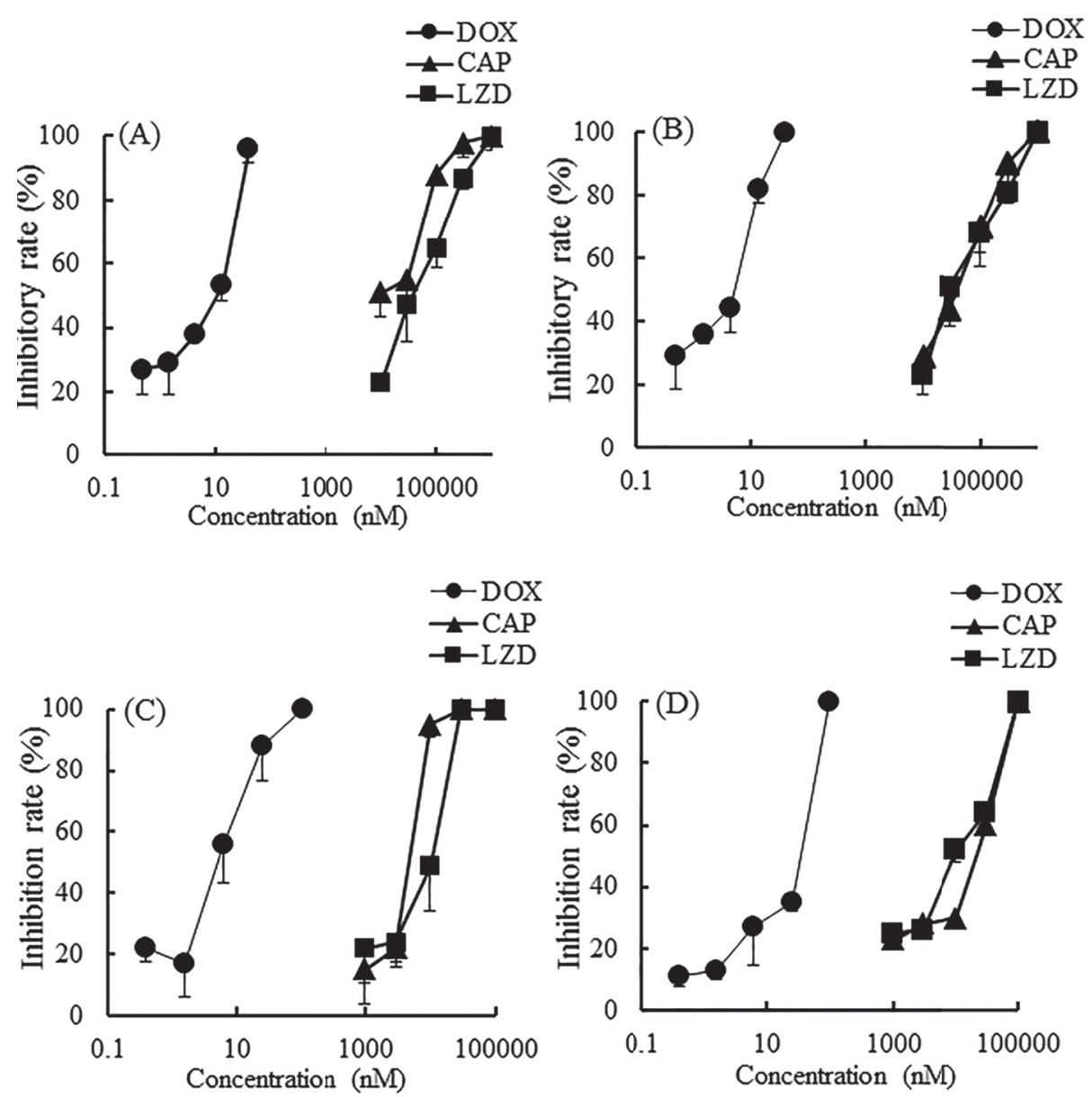

Fig. 5. Inhibitory rate of CFU-GM and BFU-E formation in monkey bone marrow mononuclear cells or human umbilical cord blood cells exposed to doxorubicin, chloramphenicol, or linezolid. Monkey bone marrow mononuclear cells and human umbilical cord blood cells were cultured for 9 days (CFU-GM) or 13 days (BFU-E). (A) monkey CFU-GM, (B) human CFU-GM, (C) monkey BFU-E, (D) human BFU-E. Data are shown as mean \pm S.D. $(n=3)$.

changing the density from $1.077 \mathrm{~g} / \mathrm{mL}$ to $1.070 \mathrm{~g} / \mathrm{mL}$ in the density gradient separation. In human bone marrow cells and peripheral blood cells, it has been reported that $\mathrm{CD} 34^{+}$hematopoietic stem/progenitor cells were enriched in low-density gradient separations, even though the total number of cells collected was decreased (Ferrero et al., 1998; Schriber et al., 1995). Taken together, we conclude that the number of monkey CFU-GM colonies increased upon changing the density from $1.077 \mathrm{~g} / \mathrm{mL}$ to $1.070 \mathrm{~g} / \mathrm{mL}$ due to the enrichment of CD34+ hematopoietic stem/ progenitor cells and increased capability to form CFUGM colonies. In contrast, monkey bone marrow cells processed by density gradient separation at $1.077 \mathrm{~g} / \mathrm{mL}$ retained the potential to make BFU-E colonies. In human bone marrow cells separated by counterflow centrifugal elutriation, it has been demonstrated that medium-sized and large $\mathrm{CD}_{3} 4^{+}$cell populations contained lineage-committed cells which had a potential to differentiate into both CFU-GM and BFU-E, whereas small CD34+ cell population included a very primitive progenitor cells possessing capable of yielding both myeloid and lymphoid lineages (Wagner et al., 1995). However, the reason why the monkey cells processed by density gradient separation at $1.077 \mathrm{~g} / \mathrm{mL}$ did not produce the sufficient number of CFU-GM colonies remains unclear because no data has been reported to show that cell density or cell size of bone marrow cells differed between monkey hematopoietic cells able to form CFU-GM and BFU-E colonies.

In the CFU-GM and BFU-E colony assays, the inhibitory effects of DOX on both CFU-GM and BFU-E colo- 
ny formation were strongest among the three compounds. DOX concentration has been reported to be about 10 to $100 \mathrm{nM}$ at $1 \mathrm{hr}$ to $48 \mathrm{hr}$ in human plasma after intravenous treatment with $50 \mathrm{mg} / \mathrm{m}^{2}$ of DOX once (Mross et al., 1988). Maximum plasma concentration $\left(\mathrm{C}_{\max }\right)$ of CAP has been shown to be $10 \mu \mathrm{g} / \mathrm{mL}(29.6 \mu \mathrm{M})$ in humans receiving repeated oral administration at $500 \mathrm{mg}$ for 1 month (Glanzko et al., 1949). It has been demonstrated that $\mathrm{C}_{\max }$ of LZD was $18.8 \mu \mathrm{g} / \mathrm{mL}(55.6 \mu \mathrm{M})$ in humans given repeated (twice daily, every $12 \mathrm{hr}$ ) oral administration of $625 \mathrm{mg}$ LZD for 14.5 days (Stalker et al., 2003). Hematotoxicity was observed in humans receiving any of these compounds, suggesting that DOX has the strongest hematotoxic potential among these compounds. This demonstrates that our results correspond to human data in vivo.

DOX strongly inhibited the formation of monkey BFU-E and human CFU-GM colonies as compared with that of human BFU-E and monkey CFU-GM, whereas CAP and LZD inhibited BFU-E colony formation for both monkeys and humans. CAP has been reported to decrease hemoglobin concentration but not leukocyte count in monkeys treated intramuscularly with CAP at 350 or $500 \mathrm{mg} / \mathrm{kg}$ for 10 days (Hrenoff, 1962). The frequency of leucopenia has been shown to be higher than that of anemia in humans given DOX (Blum and Carter, 1974). It has been reported that CAP induced erythropoietic hypoplasia with reductions of hemoglobin concentration and reticulocyte, and aplastic anemia in humans (Erslev, 1953; Malkin et al., 1990). Moreover, the frequency of anemia caused by LZD has been shown to be higher than that of myelosuppression in humans (Gerson et al., 2002). Based on this information, we considered our results to be consistent with data acquired from in vivo studies.

In the CFU-GM assay, the difference between species in susceptibility to the three compounds was as follows: human $>$ monkey for DOX, monkey $>$ human for $\mathrm{CAP}$, and human = monkey for LZD. In the BFU-E colony assay, monkey BFU-E was more susceptibility to the three compounds than human BFU-E. Because no data has been reported to compare bone marrow toxicity induced by DOX, CAP, and LZD between monkeys and humans, it is unclear whether or not our results are reproducible in vivo. However, our data obtained under the same conditions was considered to reflect the susceptibility of hematopoietic stem and progenitor cells to each compound. Therefore, we conclude that our colony assays can evaluate difference in susceptibility between species to specific compounds in hematopoietic stem and progenitor cells in vitro.

In conclusion, a monkey CFU-GM colony assay was established using bone marrow mononuclear cells proc- essed by density gradient separation at $1.070 \mathrm{~g} / \mathrm{mL}$ at final cell concentration of 1 to $3 \times 10^{4}$ cells $/ \mathrm{mL}$ for 9 days. Moreover, a monkey BFU-E colony assay can be performed using bone marrow mononuclear cells processed by density gradient separation at $1.077 \mathrm{~g} / \mathrm{mL}$ at final cell concentration of 1 to $2 \times 10^{5}$ cells $/ \mathrm{mL}$ for 13 days. Monkey CFU-GM and BFU-E colony assays established here may serve as a useful tool to evaluate the species-specific effects of drug-induced hematotoxicity in monkeys and humans.

\section{ACKNOWLEDGMENT}

The authors are thankful to the staff at the Shin Nippon Biomedical Laboratories Ltd. for their excellent technical assistance.

Conflict of interest---- The authors declare that there is no conflict of interest.

\section{REFERENCES}

Amess, J. (1993): Haematotoxicology. In: Ballantyne, B., Marrs, T., Turner, P. (Eds.), General and Applied Toxicology, vol. 1, pp.839-867, Macmillan Stockon Press, New York.

Blum, R.H. and Carter, S.K. (1974): Adriamycin. A new anticancer drug with significant clinical activity. Ann. Intern. Med., 80, 249-259.

Böttiger, L.E. and Böttiger, B. (1981): Incidence and cause of aplastic anemia, hemolytic anemia, agranulocytosis and thrombocytopenia. Acta Med. Scand., 210, 475-479.

Carlo-Stella, C., Di Nicola, M., Longoni, P., Milani, R., Milanesi, M., Guidetti, A., Haanstra, K., Jonker, M., Cleris, L., Magni, M., Formelli, F. and Gianni, A.M. (2004): Mobilization of primitive and committed hematopoietic progenitors in nonhuman primates treated with defibrotide and recombinant human granulocyte colony-stimulating factor. Exp. Hematol., 32, 68-75.

Erslev, A. (1953): Hematopoietic depression induced by chloromycetin. Blood, 8, 170-174.

Ferrero, D., Tarella, C., Cherasco, C., Bondesan, P., Omedè, P., Ravaglia, R., Caracciolo, D., Castellino, C. and Pileri, A. (1998): A single step density gradient separation for large scale enrichment of mobilized peripheral blood progenitor cells collected for autotransplantation. Bone Marrow Transplant., 21, 409-413.

Gerson, S.L., Kaplan, S.L., Bruss, J.B., Le, V., Arellano, F.M., Hafkin, B. and Kuter, D.J. (2002): Hematologic effects of linezolid: summary of clinical experience. Antimicrob. Agents Chemother., 46, 2723-2726.

Glanzko, A.J., Wolf, L.M., Dill, W.A. and Bratton, A.C.Jr. (1949): Biochemical studies on chloramphenicol (chloromycetin). II. Tissue distribution and excretion studies. J. Pharmacol. Exp. Ther., 96, 445-459.

Hrenoff, A.K. (1962): Acute toxicity of chloramphenicol to bone marrow of macaques (including blood iron studies). Med. Exp. Int. J. Exp. Med., 6, 118-122.

Malkin, D., Koren, G. and Saunders, E.F. (1990): Drug-induced aplastic anemia: pathogenesis and clinical aspects. Am. J. 
Monkey CFU-GM and BFU-E colony assays

Pediatr. Hematol. Oncol., 12, 402-410.

Mross, K., Maessen, P., van der Vijgh, W.J., Gall, H., Boven, E. and Pinedo, H.M. (1988): Pharmacokinetics and metabolism of epidoxorubicin and doxorubicin in humans. J. Clin. Oncol., 6, 517526.

Parchment, R.E. (1998): Alternative testing systems for evaluating noncarcinogenic, hematologic toxicity. Environ. Health Perspect., 106, 541-557.

Parent-Massin, D. (2001): Relevance of clonogenic assays in hematotoxicology. Cell Biol. Toxicol., 17, 87-94.

Pessina, A., Albella, B., Bueren, J., Brantom, P., Casati, S., Gribaldo, L., Croera, C., Gagliardi, G., Foti, P., Parchment, R., ParentMassin, D., Sibiril, Y. and Van Den Heuvel, R. (2001): Prevalidation of a model for predicting acute neutropenia by colony forming unit granulocyte/macrophage (CFU-GM) assay. Toxicol. In Vitro, 15, 729-740.

Schriber, J.R., Dejbakhsh-Jones, S., Kusnierz-Glaz, C.R., Ginzton, N., Still, B., Negrin, R.S., Greenberg, P. and Strober, S. (1995): Enrichment of bone marrow and blood progenitor (CD34+) cells by density gradients with sufficient yields for transplantation. Exp. Hematol., 23, 1024-1029.

Stalker, D.J., Jungbluth, G.L., Hopkins, N.K. and Batts, D.H.
(2003): Pharmacokinetics and tolerance of single- and multipledose oral or intravenous linezolid, an oxazolidinone antibiotic, in healthy volunteers. J. Antimicrob. Chemother., 51, 1239-1246.

Stephenson, J.R., Axelrad, A.A., McLeod, D.L. and Shreeve, M.M. (1971): Induction of colonies of hemoglobin-synthesizing cells by erythropoietin in vitro. Proc. Natl. Acad. Sci. USA, 68, 15421546.

Tepperman, A.D., Curtis, J.E. and McCulloch, E.A. (1974): Erythropoietic colonies in cultures of human marrow. Blood, 44, 659669.

Torti, F.M., Shortliffe, L.D., Carter, S.K., Hannigan, J.F.Jr., Aston, D., Lum, B.L., Williams, R.D., Spaulding, J.T. and Freiha, F.S. (1985): A randomized study of doxorubicin versus doxorubicin plus cisplatin in endocrine-unresponsive metastatic prostatic carcinoma. Cancer, 56, 2580-2586.

Uetrecht, J.P. (1996): Reactive metabolites and agranulocytosis. Eur. J. Haematol. Suppl., 60, 83-88.

Wagner, J.E., Collins, D., Fuller, S., Schain, L.R., Berson, A.E., Almici, C., Hall, M.A., Chen, K.E., Okarma, T.B. and Lebkowski, J.S. (1995): Isolation of small, primitive human hematopoietic stem cells: distribution of cell surface cytokine receptors and growth in SCID-Hu mice. Blood, 86, 512-523. 